\section{Roughness comparison of heat cured type of acrylic resin in disinfectant solution immersion (immersion in a solution of alkaline peroxide and $75 \%$ celery extract (apium graveolens $L$ ))}

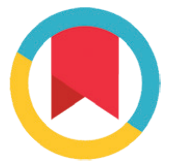

CrossMark

\author{
Dewi Puspitasari, ${ }^{1}$ Diana Wibowo, ${ }^{2}$ Elda Rosemarwa ${ }^{3 *}$
}

\begin{abstract}
Objective: The aim of the study was to find out the effect of roughness on heat cured acrylic that was immersed in alkaline peroxide and $75 \%$ celery (apium graveolens $\mathrm{L}$ ) extract as a disinfectant solution. Material and Methods: Acrylic resin denture base has the absorbing property that affects physical and mechanical properties. One of the physical properties of acrylic resin is surface roughness. It was a true experimental study and posttest with control group designed with a rectangular shape of size $65 \times 10 \times 3.3 \mathrm{~mm}$ based on the ISO standard 1567 , six samples were used for alkaline peroxide, celery extract $75 \%$ and aquadest group for 5 and 15 days. A Surface roughness tester was
\end{abstract}

used for the surface roughness changes observation. The statistical test used one-way ANOVA and post hoc bonferroni.

Results: This study showed the value of roughness on 5 days for alkaline peroxide $(1.51 \mu \mathrm{m})$ which was greater than celery extract $(0.36 \mu \mathrm{m})$ and aquadest $(0.30 \mu \mathrm{m})$. The soaking for 15 days in alkaline peroxide $(1.52 \mu \mathrm{m})$ is greater than $75 \%$ celery extracts $(0.38 \mu \mathrm{m})$ and aquadest $(0.34 \mu \mathrm{m})$.

Conclusion: Alkaline peroxide caused higher roughness value of heat cured acrylic resin than $75 \%$ celery extract.
1,3Department of Dental Materials, University of Lambung Mangkurat ${ }^{2}$ Department of Orthodontic, University of Lambung Mangkurat Banjarmasin, Indonesia
*Correspondence to: Elda Rosemarwa, Department of Dental Materials, University of Lambung Mangkurat

eldarosemarwa@yahoo.co.id

Received: 15 June 2016 Revised: 15 August 2016 Accepted: 17 August 2016 Available Online: 31 August 2016

Keywords: Acrylic, Alkaline peroxide, Celery extract, Surface roughness

Cite this Article: Puspitasari, D., Wibowo, D., Rosemarwa, E. 2016. Roughness comparison of heat cured type of acrylic resin in disinfectant solution immersion (immersion in a solution of alkaline peroxide and 75\% celery extract (Apium Graveolens L)). Journal of Dentomaxillofacial Science 1(2): 92-95. D0I:10.15562/jdmfs.v1i2.5

\section{Introduction}

Since the mid 1940's, denture base has been made using acrylic resin. ${ }^{1}$ Heat cured type acrylic resin has been widely used because it has a good aesthetic, low water absorption, and low toxicity. ${ }^{2}$ However, acrylic resin also has weakness that is its porous condition in which the food attaches so that microorganisms can proliferate in that area. ${ }^{3}$ This situation can be avoided by disinfecting denture mechanically and chemically. Mechanical disinfection is conducted by using a toothbrush and chemical disinfection by soaking the denture in a disinfectant solution. ${ }^{4}$

Disinfectant solutions have been widely circulated in the market, one of them is an effervescent tablet primarily groups of alkaline peroxide. When effervescent tablets are dissolved, it will cause removal of the denture base. ${ }^{5}$ Disinfectant chemical solutions are not only chemical base ingredients but also natural base ingredients that can be applied as a denture disinfectant because it acts as natural antifungal substance. ${ }^{6}$ One of those natural ingredients is celery (apium graveolens L.). Wulandari $\mathrm{i}^{7}$ in her research found celery extract can influence in inhibiting the growth of Candida albicans ( $C$. albicans) on acrylic resin. Celery extract with $75 \%$ concentration is the most effective concentration in inhibiting the growth of C. albicans. ${ }^{7}$ Flavonoid contained in celery is a phenolic compound that functions as an anti-bacterial and anti-fungal substance. when phenol contacts with acrylic resin, it can cause a chemical damage on the resin surface that causes roughness on acrylic resin. ${ }^{8}$ Procedures of denture cleaning performed for 20 minutes every day can lead to penetration into the pores of acrylic resin that can destroy the bacteria, so that 20 minute soaking a day for 1 year and 3 years can be simulated in 5 days and 15 days. ${ }^{9}$ Based on that, the aim of this study is to determine the difference of roughness of heat cured type acrylic resin in soaking solution of alkaline peroxide and $75 \%$ celery extract as a disinfectant for 5 days and 15 days.

\section{Material and Methods}

Type of this research is an experimental laboratory research along with post-test with only controls group design. Roughness measurements carried out in the Department of Mechanical Engineering, Faculty of Industrial Technology, 
Institute of Sepuluh Nopember Technology Surabaya. Manufacturing of acrylic plate was done in Laboratory of Dentistry, University of Lambung Mangkurat with the following procedure, samples as many as 36 pieces of dental wax was made as an aircraft model with a rectangular shape of $65 \times 10 \times 3.3 \mathrm{~mm}$ which was based on the ISO 1567 standard. Cuvette was provided and smeared with vaseline, and then dough casts was made that composed of $30 \mathrm{ml}$ water and $100 \mathrm{~g}$ of powder was added into cuvette which has been prepared on the vibrator. Wax was put on the dough and it began to harden and gypsum surface in the bottom cuvette was smeared with vaseline. Disposal wax was done by soaking cuvette in hot water which was boiling, then the cuvette was opened and the wax that still remained was discarded. When it dried, it was smeared with cold mold seal. Polymer and monomer was mixed with a ratio of 3:1 until the batter reached dough phase. Cellophane plastic was placed between the upper and lower cuvette, then it was covered and pushed with 1000 psi hydraulic press and then it was resealed and continued pressing at 2200 psi, giving pressure was continued until most of the cuvettes were close. Cuvettes were boiled in boiling water for 30 minutes. Samples were taken out from the cuvette and then the sharp part was removed by using freser bur then samples were flattened and fixed up by using a rotary grinder. The sample surface was smoothed by using bur white stone and continued using abrasive paper.

Table 1 The mean and standard deviation of heat cured type of acrylic resin roughness value

\begin{tabular}{lcc}
\hline Group & Mean \pm SD $(\mathbf{m})$ & Sig. \\
\hline 5 day Alkaline Peroxide & $1.51 \pm 0.35$ & 0.396 \\
15 day Alkaline Peroxide & $1.52 \pm 0.26$ & 0.159 \\
5 day Celery extract & $0.36 \pm 0.16$ & 0.183 \\
15 day Celery extract & $0.38 \pm 0.21$ & 0.758 \\
5 day Aquadest & $0.30 \pm 0.16$ & 0.408 \\
15 day Aquadest & $0.34 \pm 0.16$ & 0.441 \\
\hline
\end{tabular}

Celery extract production was performed at the Pharmacy Laboratory, Faculty of Mathematics and Natural Science, University of Lambung Mangkurat. Celery extract was produced using maceration method and the results obtained are filtrate and sediment. The celery filtrate was evaporated using a vacuum rotary evaporator at $70^{\circ} \mathrm{C}$. Subsequently the samples were treated, 6 samples for the group soaked for 5 days and 6 samples for the group soaked for 15 days in $75 \%$ celery extract solution and alkaline peroxide. Samples were taken out and cleaned with water and then were put on papers towel at room temperature and thereafter samples were ready for testing their surface roughness. Data processing of roughness measurement was conducted by using the surface roughness tester. Measurements were performed on samples after they were soaked in a solution of alkaline peroxide and $75 \%$ celery extract for 5 days and 15 days. Normality test was done by using the Shapiro-Wilk. Statistical analysis was performed by one-way ANOVA test with a confidence of $95 \%(\alpha=0.05)$. Significance test of the results was done by comparing the level of significance (p) with a significant level ( $\alpha$ ) 0.05 .

\section{Results}

The research results of roughness comparison of heat cured type of acrylic resin was done by soaking it in alkaline peroxide and $75 \%$ celery extract for 5 days and 15 days as follows.

Based on table 1 Shapiro-Wilk normality test, it was shown that all groups result to a significant value of $p>0.05$, which means the data are normally distributed. From the results of one-way ANOVA, p-value is $0.000(\mathrm{p}<0.05)$, which means that there are significant differences in the surface roughness value of heat cured type of acrylic resin by soaking it in alkaline peroxide and $75 \%$ celery extract. To determine which group has a signif-

Table 2 Significant differences of heat cured type of acrylic resin roughness value in soaking alkaline peroxide, celery extract $75 \%$ and aquadest

\begin{tabular}{|c|c|c|c|c|c|c|}
\hline Group & $\begin{array}{c}5 \text { days alkaline } \\
\text { peroxide }\end{array}$ & $\begin{array}{l}15 \text { days alkaline } \\
\text { peroxide }\end{array}$ & $\begin{array}{c}5 \text { days } 75 \% \text { extract } \\
\text { celery }\end{array}$ & $\begin{array}{c}15 \text { days } 75 \% \text { extract } \\
\text { celery }\end{array}$ & $\begin{array}{l}5 \text { days } \\
\text { aquadest }\end{array}$ & $\begin{array}{c}15 \text { days } \\
\text { aquadest }\end{array}$ \\
\hline 5 days alkaline peroxide & & 1.000 & $0000^{*}$ & 1.000 & $0000 *$ & 1.000 \\
\hline 15 days alkaline peroxide & & & 1.000 & $0.000^{*}$ & 1.000 & $0.000^{*}$ \\
\hline 5 days $75 \%$ extract celery & & & & 1.000 & 1.000 & 1.000 \\
\hline 15 days $75 \%$ extract celery & & & & & 1.000 & 1.000 \\
\hline 5 days aquadest & & & & & & 1.000 \\
\hline 15 days aquadest & & & & & & \\
\hline
\end{tabular}

Note: ${ }^{*}$ significant difference at $\mathrm{p}<0.05$ 
at differences between the treatment groups, i.e., between alkaline peroxide, celery extract, and distilled water shown in table 2.

On immersing in alkaline peroxide group and distilled water for 5 days and 15 days, there are significant differences. In the group immersed by celery extract $75 \%$ and distilled water for 5 days and 15 days, there is no significant difference. In the group immersed by alkaline peroxide and $75 \%$ celery extract for 5 days and 15 days, there are significant differences. In the group of 5 day alkaline peroxide immersion, there is no significant difference with 15 day alkaline peroxide group. In the group immersed by $75 \%$ celery extract for 5 days, there is no significant difference with the group of $75 \%$ celery extract immersed for 15 days.

\section{Discussion}

Based on the research results, a group immersed in alkaline peroxide with distilled water for 5 and 15 days, there is a significant difference, this is caused by a chemical reaction of alkaline peroxide tablet or powder dissolved into water to produce sodium perborate and will break down again into hydrogen peroxide, when contact occurs with certain substances, it will cause the release of small bubbles of oxygen (nascent oxygen) with a mechanical action separating the biofilm from the denture surface. ${ }^{10,11}$ These results are also supported by Jagger and Harrison cit Malheiros et al..$^{13}$ that bubbles formed by the release of oxygen during the reaction process may cause surface roughness. There are adverse effects of oxygen that is associated with a strong oxidation from solution so that oxygen released causes the tertiary amine to accelerate oxidation or unreacted double bonds in the acrylic resin matrix that will change the physical properties such as surface roughness of acrylic resin. ${ }^{14}$

Group immersed in $75 \%$ celery extract with distilled water for 5 and 15 days has no significant difference due to the content of celery extract that is flavonoids. The results of this research are supported by Wulandari et al. ${ }^{8}$ found phenol when in contact with acrylic resin can cause chemical damage on the resin surface that causes roughness on acrylic resin. ${ }^{8}$ Research by Collares et al..$^{15}$ also found that ethanol extracts that pass into the matrix will widen space between the chain, causing the separation of the polymer chains to easily deforms plastically and cause roughness on acrylic resin.

Five days and 15 days immersion of alkaline peroxide and $75 \%$ celery extract, perform a significant difference due to factors described above, one of which is a long contact time between the solution and treatment group sample. In the group of alkaline peroxide immersed for 5 days and 15 days, there is no significant difference in statistical tests and also on group celery extract $75 \%$ was immersed for 5 days and 15 days. However, from the roughness results, there is a difference between 5-days and 15-days immersion. Water absorption can be affected by the occurrence of diffusion. Diffusion is a process of the substance migration through the cavity that causes the expansion of the resin or through a substance that can affect the strength of the polymer chain.

Based on this research, there is significant difference between acrylic resin soaked in an alkaline peroxide solution and $75 \%$ celery extract for 5 days and 15 days and there is a significant difference between the acrylic resin immersed in an alkaline peroxide solution and distilled water for 5 days and 15 days. In contrast to the case of $75 \%$ celery extract solution and distilled water for 5 days and 15 days there is no significant difference. Alkaline peroxide causes roughness values greater than $75 \%$ celery extract.

\section{Conflict of Interest}

The authors report no conflict of interest.

\section{References}

1. Anusavice KJ. In Johan Arief Budiman SPE, editor. Phillips buku ajar ilmu bahan kedokteran gigi. Jakarta: EGC; 2013. p. 197.

2. Bahrani F, Safari A, Vodjani M, et al. Comparison of hardness and surface roughness of two denture bases polymerized by different methods. World J Dentistry 2012;3: 171-175.

3. Hashem M, Alsaleem SO, Assery MK, et al. A comparative Study of the mechanical properties of the light-cure and conventional denture base resins. OHDM 2014;13: 311-315.

4. Wahyuningtyas E. Pengaruh ekstrak graptophyllum pic- tum terhadap pertumbuhan candida albicans pada plat gigi tiruan resin akrilik. Indonesian J Dentistry 2008;15: 187-191.

5. Sahin DC, Ayyildiz DS, Ergin DA, et al. Effect of chemical denture cleansers on microorganisms over heatpolymerized acrylic resin. African J Dentistry 2013;1: 6-9.

6. Hermawati IR, Sudarno, Handijatno D. Uji potensi anti- fungal perasan daun seledri (apium graveolens L) terhadap aspergillus terreus secara in vitro. Jurnal Ilmiah Perikanan dan Kelautan 2014;6: 37-42.

7. Wulandari AP. Pengaruh konsentrasi ekstrak seledri (apium graveolens L) terhadap pertumbuhan candida albicans pada resin akrilik. Yogyakarta: Universitas Muhammadiyah Yogyakarta; 2013. p. 1-40.

8. Wulandari F, Rostiny, Soekobagiono. Pengaruh lama per- endaman resin akrilik heat cured dalam eugenol min-yak kayu manis terhadap kekuatan transversa. J Prostho 2012;13: 1-5.

9. Pisani MX, Silva CHLD, Paranhos HDFO, et al. The effect of experimental denture cleanser solution ricinus communis on acrylic resin properties. Materials Research 2010;13: 369-373. 
10. Chittaranjan B, Taruna, Sudhir, et al. Material and methods for cleaning the denture. Indian J Dent Advancement 2011;3: 424.

11. Andrade IM, Cruz PC, Silva CH, et al. Effervescent tablets and ultrasonic devices against candida and mutans streptococci in denture biofilm. Gerodontol 2011;28: 264-265.

12. Shamnur SN, Jagadeesh KN, Kalavathi SD, et al. Flexible dentures an alternate for rigid dentures. J Dent Sci Research 2010;1: 74-76.

13. Malheiros AL, Pisani MX, Paranhos HF, et al. Effect of a denture cleanser on hardness roughness and tensile bond strength of denture liners. Braz J Oral Sci 2008;7: 1596.

14. Lira AFd, Consani RLX, Mesquita MF, et al. Surface hardness of acrylic resins exposed to tooth brushing, chemical disinfection and thermocycling. J Research \& Practice in Dentistry 2014: 1-9.

15. Collares FM, Rostirolla FV, Macedo EDODD, et al. Influence of mouthwashes on the physical properties of orthodontic acrylic resin. Braz J Oral Sci 2014;13: 203-208..

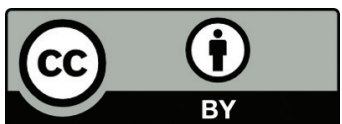

This work is licensed under a Creative Commons Attribution 